Right Here on Our Stage Tonight! 
The publisher gratefully acknowledges the generous support of the Art Endowment Fund of the University of California Press Foundation, which was established by a major gift from the Ahmanson Foundation. 


\section{Gerald Nachman}

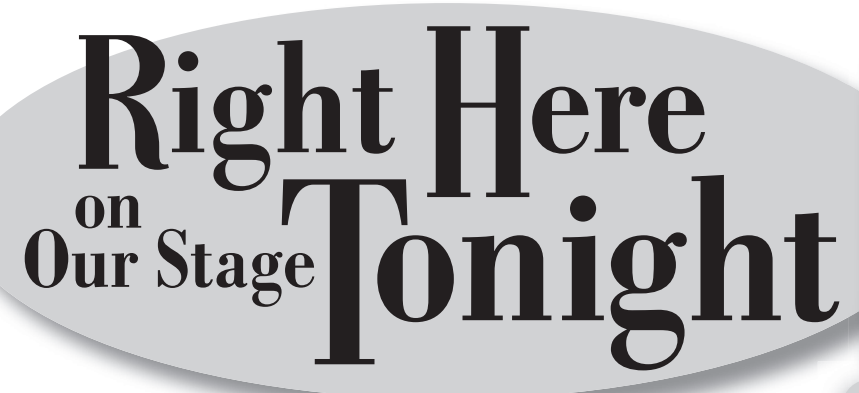

Ed Sullivan's

America

甲

UNIVERSITY OF CALIFORNIA PRESS

Berkeley · Los Angeles . London 
University of California Press, one of the most distinguished university presses in the United States, enriches lives around the world by advancing scholarship in the humanities, social sciences, and natural sciences. Its activities are supported by the UC Press Foundation and by philanthropic contributions from individuals and institutions. For more information, visit www .ucpress.edu.

University of California Press

Berkeley and Los Angeles, California

University of California Press, Ltd.

London, England

(C) 2009 by The Regents of the University of California

Library of Congress Cataloging-in-Publication Data

Nachman, Gerald.

Right here on our stage tonight! : Ed Sullivan's America / Gerald Nachman.

p. $\mathrm{cm}$.

Includes bibliographical references and index.

ISBN 978-0-520-25867-9 (cloth : alk. paper)

I. Ed Sullivan show (Television program).

2. Sullivan, Ed, I902- 3. Television personalitiesUnited States-Biography. I. Title.

PNI992.77.E35 332009

79I.45'75-dc22

$200900335 \mathrm{I}$

Manufactured in the United States of America
I 8 I7 76 I5 5 I4 I3 I2 II IO 09
IO $9 \begin{array}{lllllllll}9 & 8 & 7 & 6 & 5 & 4 & 3 & 2 & \text { I }\end{array}$

This book is printed on Cascades Enviro ı००, a I००\% post consumer waste, recycled, de-inked fiber. FSC recycled certified and processed chlorine free. It is acid free, Ecologo certified, and manufactured by BioGas energy. 
In memory of Marshall Jacobs and

Ray Golden, two talented lovers of talent 
This page left intentionally blank 
Ed . . . is so aware of talent-so struck with the splendor of it-so altogether stage struck, in the true sense of the phrase, that one can actually feel it.

Helen Hayes in Collier's, 1956 
This page left intentionally blank 